\title{
HUBUNGAN PENGETAHUAN KELUARGA TENTANG PERSONAL HYGIENE DENGAN KEMAMPUAN KELUARGA MERAWAT ANGGOTA KELUARGA YANG MENGALAMI GANGGUAN JIWA
}

\section{THE RELATIONSHIP BETWEEN FAMILY KNOWLEDGE OF PERSONAL HYGIENE AND FAMILY CAPABILITY IN NURSING THE MEMBER OF FAMILY WITH MENTAL DISORDER AT MANISRENGGO DISTRICT, KLATEN}

\author{
Retno Yuli Hastuti, Adik Kristin Varlinda \\ Prodi S1 Keperawatan Stikes Muhammadiyah Klaten \\ e-mail: hastuti.puteri@gmail.com
}

\begin{abstract}
Abstrak
Orang dengan gangguan jiwa adalah orang yang mengalami gangguan dalam pikiran, perilaku, dan perasaan yang termanifestasi dalam bentuk sekumpulan gejala dan atau perubahan perilaku yang bermakna, serta dapat menimbulkan penderitaan dan hambatan dalam menjalankan fungsi orang sebagai manusia. Menganalisa hubungan pengetahuan keluarga tentang personal hygiene dalam merawat penderita yang mengalami gangguan jiwa. Penelitian ini menggunakan desain deskriptif korelasi dengan pendekatan cross sectional. Populasi penelitian ini adalah keluarga yang mempunyai anggota keluarga yang mengalami gangguan jiwa di kecamatan manisrenggo sebanyak 46 keluarga. Jumlah sampel penelitian ini sebanyak 40 responden dengan total sampling. Analisa data menggunakan Kendal Tau. Hasil penelitian menunjukan bahwa respoden dengan pengetahuan baik sejumlah 26 orang (65,0\%) dan kemampuan merawat mampu sejumlah 23 $(57,5 \%)$. Berdasrkan analisis menggunkan uji Kendal tau di peroleh Koefisien korelasi yaitu 0,000 dan nilai $\alpha=0,05, C I=95 \%$. Hal ini berarti semakin tinggi pengetahuan keluarga semakin bertambah pula kemampuan keluarga merawat. Hasil dari penelitian disimpulkan ada hubungan antara pengetahuan keluarga tentang personal hygiene dengan kemampuan keluarga merawat anggota keluarga yang mengalami gangguan jiwa di Kecamatan ManisrenggoKabupatenKlaten.
\end{abstract}

Kata Kunci: Gangguan jiwa, pengetahuan keluarga, kemampuan keluarga.

\begin{abstract}
People with mental disorders are people with impaired in mind, behavior, and feelings which are manifested in the form of a set of symptoms or significant behavioral changes, and can cause suffering and obstacles in functioning as a human person. The aim of this study to analyze the relationship of family knowledge about personal hygiene in caring for patients which mental disorder. This research used descriptif correlation design with time approach cross sectional. The population research was family which had family members whom experiencd a mental disorder in the Manisrenggo district, Klaten. The amount of sample research were 40 samples took by using total sampling. Data analyzed by using Kendal tau. The results showed that respondents with a good knowledge of a number of 26 people (65.0\%) and the ability to afford care for a number of 23 (57.5\%). Based on analysis by using the test Kendal tau obtained. The correlation coefficient is 0.000 and the value of $\alpha=0.05, C I=95 \%$. This means that the higher the family knowledge from the family it is ability to care for is also increasing. The results of the research, concluded that there is a correlation between family knowledge about personal hygiene with the family's to care their family members with mental disorder in the Manisrenggo. district of Klaten regency.
\end{abstract}

Keywords: Mental disorders, family knowledge, to care their family 


\section{PENDAHULUAN}

Kesehatan jiwa adalah kondisi dimana seorang individu dapat berkembang secara fisik, mental, spiritual, dan sosial sehingga individu tersebut menyadari kemampuan sendiri, dapat mengatasi tekanan, dapat bekerja secara produktif, dan kemampuan memberikan kontribusi untuk komunitasnya. Orang dengan masalah kejiwaan adalah orang yang mempunyai masalah fisik, mental, sosial, pertumbuhan dan perkembangan, dan/atau kualitas hidup sehingga memiliki risiko mengalami gangguan jiwa (UU No /18/2014). Gangguan jiwa merupakan salah satu dari 4 masalah kesehatan utama dinegara maju, modern dan industri. Meskipun gangguan jiwa tersebut tidak dianggap sebagai gangguan yang menyebabkan kematian secara langsung namun beratnya gangguan tersebut dalam arti ketidakmampuan serta identitas secara individu maupun keluarga akan menghambat pertumbuhan karena mereka tidak produktif dan tidak efisien (Hawari,2001).

Prevalensi gangguan jiwa berat berdasarkan Data Riset Kesehatan Dasar (Riskesdes) tahun 2013 terbanyak yaitu 2,7 per mil adalah DIY dan Aceh. Prevalensi gangguan jiwa berat pada penduduk Indonesia 1,7 per mil. Secara Nasional terdapat $0,17 \%$ penduduk Indonesia yang mengalami gangguan mental berat (Skizofrenia) atau secara absolute terdapat 400 ribu jiwa lebih penduduk Indonesia. Provinsi Jawa Tengah sebanyak 92.000 orang. Dari data riset kesehatan dasar dari keseluruhan yang mengalami gangguan jiwa 1,3\% penderita gangguan jiwa berada di rumah dan rawat jalan.

Keperawatan jiwa mempelajari berbagai macam kasus yang berhubungan dengan gangguan jiwa seseorang. Salah satunya adalah defisit perawatan diri. Kurang perawatan diri pada pederita dengan gangguan jiwa merupakan : suatu keadaan dimana seseorang mengalami kerusakan kemampuan untuk melakukan atau menyelesaikan (kegiatan hidup sendiri). Kurangnya perawatan diri pada pasien dengan gangguan jiwa terjadi akibat adanya perubahan proses pikir sehingga kemampuan untuk melakukan aktivitas perawatan diri menurun. Kurang perawatan diri tampak dari ketidak mampuan merawat kebersihan diri, makan secara mandiri, berhias diri secara sendiri, dan toileting buang air besar/ buang air kecil ( Damayanti, 2008).

Beberapa faktor yang dapat mempengaruhi penderita kurang perawatan diri di rumah antara lain pengetahuan, pendidikan, informasi, sosial ekonomi, peran keluarga. (Wawan \& Dwi, 2010). Berdasarkan hasil penelitian (Hasriana, 2013) berasumsi bahwa semakin tinggi pendidikan seseorang maka semakin baik pula pengetahuan terhadap personal hygiene, sebaliknya semakin rendah pendidikan seseorang maka semakin kurang pula pengetahuan terhadap personal hygiene.

Keluarga sebagai sumber dukungan sosial dapat menjadi faktor kunci dalam penyembuhan penderita gangguan jiwa. Walaupun anggota keluarga tidak selalu merupakan sumber positif dalam kesehatan jiwa, mereka paling sering menjadi bagian penting dalam penyembuhan (Videbeck, 2008). Keberhasilan perawat di rumah sakit dapat sia-sia jika tidak di teruskan di rumah yang kemudian mengakibatkan penderita harus di rawat kembali (kambuh).

Salah satu faktor penyebab terjadinya kekambuhan penderita skizofrenia adalah kurangnya peran serta dukungan sosial yang di berikan keluarga dalam perawatan terhadap anggota keluarga yang menderita penyakit tersebut. Salah satu penyebabnya adalah karena keluarga yang tidak tahu cara menangani perilaku penderita di rumah (Friedman, 2010). Disinilah dukungan sosial sangat di butuhkan dalam memberikan perawatan pada penderita skizofrenia, karena dukungan sosial dari orang lain menjadi sangat berharga dan akan menambah semangat hidupnya.

\section{METODE PENELITIAN}

Desain penelitian ini merupakan penelitian deskriptif korelasi dengan pendekatan cross sectional. Penelitian ini dilaksanakan diKecamatan Manisrenggo Kabupaten Klaten. Populasi dalam penelitian ini adalah keluarga yang mempunyai anggota keluarga yang mengalami gangguan jiwa di Kecamatan Manisrenggo Kabupaten Klaten berjumlah 46 keluarga. Teknik pengampilan sampel dengan tekhnik total sampling atau sampling jenuh dengan $\mathrm{k}$ riteria ekslusi diperoleh besar sampel 40 responden. Instrumen yang digunakan untuk mengukur variabel pengetahuan keluarga tentang personal hygiene dan kemampuan keluarga merawat menggunakan kuesioner yang belum valid maka perlu di uji validitas dengan Pearson Product Moment dan reliabilitas dengan Kuder-richardson (K-R 20). Analisa bivariat yang digunakan untuk mengetahui hubungan antara variabel 
pengetahuan keluarga tentang personal hygiene dengan kemampuan keluarga merawat anggota keluarga yang mengalami gangguan jiwa menggunakan uji statistic Kendal-Tau.

\section{HASIL PENELITIAN DAN PEMBAHASAN}

Penelitian tentang hubungan pengetahuan keluarga tentang personal hygiene dengan kemampuan keluarga merawat anggota keluarga yang mengalami gangguan jiwa di Kecamatan Manisrenggo Kabupaten Klaten. Jumlah keluarga yang mempunyai penderita gangguan jiwa terhitumg pada bulan Juni 2015 berjumlah 46 keluarga. Responden yang digunakan dalam penelitian ini berjumlah 40 responden.

\section{Analisis Univariat}

1. Usia

Tabel 1. Rerata Karakteristik Responden yang Memiliki Anggota Keluarga yang Mengalami Gangguan Jiwa di Kecamatan Manisrenggo Kabupaten Klaten Tahun 2015

\begin{tabular}{ccccccc}
\hline \multicolumn{1}{c}{ Usia } \\
\hline & $\mathrm{N}$ & $\min$ & $\max$ & median & mean & std \\
\hline usia & 40 & 32 & 78 & 55,5 & 56,32 & 12,90 \\
\hline
\end{tabular}

Tabel 1. di atas diketahui bahwa rata-rata umur responden pada penelitian ini adalah 56 tahun dengan umur minimal responden 32 tahun dan maksimal 78 tahun.

b. Jenis Kelamin, pendidikan, pekerjaan, hububungan dengan penderita, penghasilan, pengalaman, pengetahuan dan kemampuan keluarga merawat.

Tabel 2. Distribusi Frekuensi Karakteristik Responden Keluarga Yang Memiliki Anggota Keluarga Yang Mengalami Gangguan Jiwa di Kecamatan Manisrenggo Kabupaten Klaten Tahun 2015

\begin{tabular}{lcc}
\hline \multicolumn{1}{c}{$\begin{array}{c}\text { Karakteristik } \\
\text { responden }\end{array}$} & $\begin{array}{c}\text { Frekuensi } \\
\text { (f) }\end{array}$ & $\begin{array}{c}\text { Prosentase } \\
(\%)\end{array}$ \\
\hline Jenis kelamin & & \\
Laki-laki & 10 & 25.0 \\
Perempuan & 30 & 75.0 \\
\hline Pendidikan keluarga & & \\
SD & 19 & 47.5 \\
SLTP & 9 & 22.5 \\
\hline
\end{tabular}

\begin{tabular}{lcc}
\hline SMU & 9 & 22.5 \\
PT & 3 & 7.5 \\
\hline Pekerjaan & & \\
Bekerja & 34 & 85.0 \\
Tidak bekerja & 6 & 15.0 \\
\hline Pengalaman & & \\
merawat & 9 & 22.5 \\
5-6 tahun & 14 & 35.0 \\
7-9 tahun & 17 & 42.5 \\
>10 tahun & & \\
\hline Hubungan dengan & & \\
penderita & & \\
Ayah & 3 & 7.5 \\
Ibu & 19 & 47.5 \\
Suami & 6 & 15.5 \\
Istri & 2 & 5.0 \\
Anak & 3 & 7.5 \\
Kakak & 7 & 17.5 \\
\hline Penghasilan & & \\
<Rp. 500.000,- & 6 & 15.0 \\
Rp.500.000- & 18 & 45.0 \\
Rp1.000.000,- & 16 & 40.0 \\
>Rp. 1000.000,- & & \\
\hline Pengetahuan & & \\
Baik & 26 & 65.0 \\
Cukup & 14 & 35.0 \\
Kurang & - & - \\
\hline Kemampuan & & \\
Mampu & & \\
Cukup mampu & 23 & 57.5 \\
Kurang mampu & 17 & 42.5 \\
\hline & - & - \\
\hline & & \\
& & \\
\hline & & \\
\hline
\end{tabular}

Tabel 2 menunjukan sebagian besar responden berjenis kelamin perempuan $(75,0 \%)$, dengan tingkat pendidikan terbanyak lulusan SD $(47,5 \%)$ responden sebagian besar bekerja $(85,0 \%)$ dengan penghasilan responden rata-rata Rp.500.000- Rp.1.000.000 $(45,0 \%)$, sedangkan pengalaman keluarga merawat anggota keluarga yang mengalami gangguan jiwa terbanyak > 10 tahun $(42,5 \%)$, diketahui hubungan responden dengan penderita sebagian banyak hubungana sebgai ibu (47,5\%). Hasil penelitian menunjukan dari 40 responden, 23 responden $(57,5)$ mampu merawat anggota keluarga yang mengalami gangguan jiwa. 


\section{Analisis Bivariat}

Tabel 3. Hubungan Pengetahuan Keluarga Tentang Personal Hygiene dengan Kemampuan Keluarga Merawat Anggota Keluarga yang Mengalami Gangguan Jiwa di Kecamatan Manisrenggo Kabupaten Klaten Tahun 2015

\begin{tabular}{|c|c|c|c|c|c|c|c|c|c|}
\hline & \multicolumn{6}{|c|}{$\begin{array}{c}\text { Kemampuan keluarga } \\
\text { Merawat }\end{array}$} & \multirow{2}{*}{\multicolumn{2}{|c|}{ Total }} & \multirow{2}{*}{ p value } \\
\hline & \multicolumn{2}{|c|}{ mampu } & \multicolumn{2}{|c|}{ Cukup mampu } & \multicolumn{2}{|c|}{ Kurang mampu } & & & \\
\hline & $\mathrm{f}$ & $\%$ & $\mathrm{f}$ & $\%$ & $\mathrm{f}$ & $\%$ & $\mathrm{f}$ & $\%$ & \\
\hline \multicolumn{10}{|c|}{ Pengetahuan keluarga } \\
\hline Baik & 21 & 52,5 & 5 & 12,5 & 0 & 0 & 26 & 65,0 & 0,000 \\
\hline Cukup & 2 & 5,0 & 12 & 30,0 & 0 & 0 & 14 & 35,0 & \\
\hline \multicolumn{10}{|l|}{ Kurang } \\
\hline Jumlah & 23 & 57,5 & 17 & 42,5 & 0 & 0 & 40 & 100 & \\
\hline
\end{tabular}

Tabel 3. menunjukan bahwa dari 40 responden yang memiliki pengetahuan baik $65,0 \%$ dengan kemampuan merawat mampu $52,5 \%$ dan kemampuan merawat cukup $12,5 \%$. Sedangkan responden dengan pengetahuan cukup $35,0 \%$ dengan kemampuan merawat mampu $5 \%$ dan kemampuan merawat cukup mampu 30,0\%.

Hasil analisis bivariat diketahui bahwa $p$ value dari hasil analisis data diperoleh $\mathrm{p}=$ 0,000 berarti $p<0,05$ sehingga ada hubungan antara pengetahuan keluarga tentang personal hygiene dengan kemampuan keluarga merawat anggota keluarga yang mengalami gangguan jiwa.

\section{PEMBAHASAN}

\section{A. Karakteristik Responden}

Hasil penelitian didapatkan usia rata-rata keluarga penderita yang mengalami gangguan jiwa 56 tahun. Usia rata-rata 56 tahun menurut Depkes RI dalam Bandiyah (2009), termasuk kedalam masa lansia akhir. Usia keluarga penderita yang mengalami gangguan jiwa ini merupakan usia yang cukup matang dalam pengalaman hidup dan kematangan jiwanya untuk membantu dalam merawat penderita yang mengalami gangguan jiwa. Usia berhubungan dengan keputusan untuk menggunakan pelayanan kesehatan jiwa dimana semakin bertambah usia seseorang maka semakin besar kepercayaannya untuk mencari pertolongan kesehatan terutama dalam keluarga adalah berhubungan dengan kematangan untuk memperhatikan anggota keluarga lain yang butuh pertolongan kesehatan.

Sebagian besar $(47,5 \%)$ keluarga penderita yang mengalami gangguan jiwa berpendidikan SD. Semakin tinggi tingkat pengetahuan seseorang semakin baik dalam kemampuan keluarga merawat penderita yang mengalami gangguan jiwa. Seseorang yang berpendidikan tinggi maka akan semakin baik pula proses pemahaman dalam pemahaman dalam menerima informasi baru karena pendidikan diperlukan untuk mendapatkan informasi (Notoatmodjo, 2010). Hal ini karena seseorang yang berpendidikan tinggi akan memiliki pengetahuan yang luas serta kemampuan untuk menerima informasi lebih tinggi

Keluarga klien penderita yang mengalami gangguan jiwa dari hasil penelitian didapatkan data bahwa sebagian besar (75\%) berjenis kelamin perempuan. Dimana perempuan terutama yang berperan sebagai seorang ibu, rata-rata mempunyai ketelatenan dan dasar naluri dalam merawat keluarga atau anggota keluarga yang sakit.

Hasil penelitian memperlihatkan hasil bahwa keluarga penderita yang mengalami gangguan jiwa sebagian besar (85\%) bekerja, secara umum pekerjaan ini berhubungan dengan dengan kemampuan keluarga dengan pertimbangan bahwa peran keluarga dalam merawat anggota keluarga yang mengalami gangguan jiwa memerlukan waktu luang yang cukup dalam memberikan perawatan kepada penderita, sehingga bagaimana mengatur antara bekerja 
dengan peran tersebut. Hasil penelitian ini menunjukan bahwa sebagian besar responden bekerja (85\%), dan yang tidak bekerja sebanyak $(15 \%)$. Apabila dilihat dari jenis pekerjaan maka sebagian besar responden yang bekerja lebih banyak dari pada yang tidak bekerja. Pada responden yang bekerja waktu yang dipunyai habis digunakan untuk bekerja dan menyelesaikan pekerjaan rumah tangga sehingga kesempatan untuk merawat anggota keluarga yang mengalami gangguan jiwa menjadi terbatas.

Hubungan keluarga dengan penderita didapatkan bahwa sebagian besar (47,5\%) mempunyai hubungan dengan penderita sebagi ibu atau orang tua. Peran sebagai ibu mempunyai hubungan emosional yang cukup erat dalam keluarga, hal ini merupakan dukungan internal, seperti dukungan dari ayah, ibu, suami,istri atau dukungan dari saudara kandung atau dukungan keluarga eksternal (Friedman, 2009). Hasil penelitian yang didapatkan ini menggambarkan bahwa hubungan dengan penderita ini walaupun terkategori cukup dekat, tetapi pengembangan koping keluarga sudah cukup baik, apalagi dengan hasil memberikan perawatan kepada penderita yang mengalami gangguan jiwa ini dan keluarga mendapatkan suatu perkembangan pengobatan dan perawatan penderita yang cukup baik pula, tentunya akan membuat keluarga dengan kedekatan hubungan tersebut merasakan sudah cukup mampu dalam memberikan perawatan.

Berdasarkan hasil penelitian menunjukan bahwa pengalaman keluarga merawat penderita yang mengalami gangguan jiwa $(42,5 \%)$ yaitu sebagian besar merawat penderita yang mengalami gangguan jiwa selam $>10$ tahun. Hal ini akan meningkatkan pemahaman keluarga dalam merawat anggota keluarga yang sedang sakit sehingga keluarga akan berusaha melakukan pengobatan, keadaan ini dapat menekan terjadinya kekambuhan sehingga mampu memberikan perawatan kepada penderita yang mengalami gangguan jiwa.

Penelitian menunjukan bahwa sebagian besar penghasilan keluarga Rp.500.000Rp1.000.000 sebanyak (45\%). Penghasilan merupakan sebuah faktor resiko yang sangat menentukan dalam mencari fasilitas kesehatan jiwa. Penghasilan keluarga mempengaruhi peran keluarga dalam penyembuhan dan dalam memberikan perawatan bagi penderita. Faktor penghasilan rendah bisa menjadi penyebab kekambuhan karena keluarga tidak sanggup mencukupi kebutuhan penderita seperti membawa ketempat pelayanan kesehatan untuk sekedar membelikan obat bagi penderita. Oleh karena itu dapat dirasakan penghasilan berpengaruh terhadap kemampuan keluarga merawat anggota keluarga yang mengalami gangguan jiwa.

\section{B. Pengetahuan Keluarga}

Hasil penelitian menunjukan bahwa responden dengan pengetahuan baik sebanyak 26 $(65 \%)$ orang terdapat $21(52,5 \%)$ orang dengan kemampuan merawat mampu dan cukup mampu sebanyak $5(12,5 \%)$ orang. Hasil penelitian menunjukan bahwa responden dengan pengetahuan cukup sebanyak 14 (35\%) orang, dari angka tersebut ada yang berkemampuan merawat mampu sebanyak $2(5 \%)$ orang dan cukup mampu sebanyak $12(30 \%)$ sorang. Didukung penelitian Riyandindi (2011) menyebutkan bahwa tingkat pengetahuan keluarga merawat penderita skizofrenia sebagian besar adalah tinggi $(55,6 \%)$.

Tingkat pendidikan turut menentukan mudah tidaknya keluarga menyerap dan memahami pengetahuan tentang cara merawat penderita yang mengalami gangguan jiwa yang mereke peroleh. Notoatmodjo (2007) juga mengatakan pengetahuan kognitif merupakan domain yang sangat penting bagi terbentuknya tindakan seseorang. Apabila penerima oerilaku baru disadari oleh pengetahuan, kesdaran dan sikap yang poritis perilaku tersebut akan bersifat langgeng (Long Lasting).

Hasil menunjukan pada penelitian ini responden dalam pengetahuan baik, hal ini dimungkinkan dari kriteria keluarga yang diambil dalam penelitia ini adalah keluarga penderita yang pernah dirawat. Semakin banyak informasi yang masuk semakin banyak pula pengetahuan yany didapat tentang kesehatan. Pengetahuan sangat erat kaitannya dengan pendididkan dimana seseorang dengan pendidikan tinggi, maka orang tersebut akan semakin luas pula pengetahuannya. Namun perlu ditekankan bahwa seseorang yang berpendidikan rendah tidak berarti mutlak berpengetahuan rendah pula, peningkatan pengetahuan tidak mutlak diperoleh dipendidikan formal, akan tetapi juga diperoleh pada pendidikan non formal. 


\section{Kemampuan Keluarga Merawat}

Berdasarkan tabel 4.9 hasil penelitian didapatkan sebanyak 23 orang $(57,5 \%)$ mempunyai kemampuan merawat dengan mampu dan sebanyak 17 orang $(42,5 \%)$ mempunyai kemampuan merawat dengan cukup. Kemampuan keluarga merupaka gabungan pengetahuan dan sikap keluarga dalam merawat penderita yang mengalami gangguan jiwa.

Peneliti berpendapat bahwa ketidakmampuan keluarga bisa disebabkan karena keluarga mengalami kelelahan secara fisik maupun mental selama merawat anggota keluarga yang mengalami gangguan jiwa, karena usia responden yang rata-rata sudah lansia. Dampak yang dirasakan keluarga selama merawat penderita yang kelelahan atau merawat terlalu lama mempengaruhi sikap keluarga dalam memberikan perawatan bagi penderita sehingga kemampuan keluarga menjadi kurang baik. Teschinsky (2007) juga menjelaskan bahawa keluarga yang merawat anggota keluarga dengan gangguan jiwa akan mengalami reaksi emosi yang tinggi pula dan kelelahan yang bertambah juga.

Anggota keluarga dengan gangguan jiwa memerukan perawatan berkelanjutan. Oleh karena itu diperlukan peran serta keluarga dalam merawat penderita gangguan jiwa baik itu dirawat inap maupun yang rawat jalan dirumah sakit atau fasilitas kesehatan lainnya, keluarga harus tetap memberiksn perhatian dan dukungan sesuai petunjuk tim medis atau petugas kesehatan lainnya. Dukungan keluarga sangat diperlukan oleh penderita gangguan jiwa dalam memotivasi mereka selama perawatan dan proses pemulihan.

\section{Hubungan Pengetahuan Keluarga dengan Kemampuan Keluarga Merawat}

Hasil penelitian menunujukan bahawa dari 40 responden nilai $r=605$ artinya semakin tinggi pengetahuan keluarga semakin bertambah kemampuan keluarga. Berdasarkan hasil uji bivariat dengan menggunakan Kendal tau melalui program spss, didapatkan nilai signifikan sebesar $0,000<0,005$, yang berarti pada penelitian ini ada hubungan yang signifikan antara pengetahuan keluarga tentang personal hygiene dengan kemampuan keluarga merawat anggota keluarga yang mengalami gangguan jiwa.

Hasil penelitian ini menunjukan bahwa ada hubungan yang signifikan antar pengetahuan dengan kemampuan keluarga. Sesuai dengan kerangka konsep dan kerangka teori yang diung- kapkan dibab terdahulu. Kemampuan keluarga dalam memberikan perawatan yang tepat pada anggota keluarga yang mengalami gangguan jiwa adalah kategori mampu dan cukup. Hasil penelitian terlihat, masih terdapat responden yang memberikan tindakan kesehatan yang kurang tepat untuk anggota keluarganya yang mengalami gangguan jiwa, ini dibuktikan dari jawaban responden bahwa responden merasa bingung ketika dihadapi masalah gangguan jiwa yang diderita anggota keluarganya, dimana keluarga tidak mengerti masalah yang terjadi dalam keluarganya yang membuat keputusan yang tepat dan cepat. Kurangya kemampuan keluarga dalam memberikan perawatan bagi anggota keluarganya bukan hanya dari pengetahuan, pada penelitian ini jenis kelamin, usia, serta penghasilan dari responden juga berpengaruh pada kemampuan.

Hasil penelitian menunujukan bahawa dari 40 responden nilai $r=605$ artinya semakin tinggi pengetahuan keluarga semakin bertambah kemampuan keluarga. Berdasarkan hasil uji bivariat dengan menggunakan Kendal tau melalui program spss, didapatkan nilai signifikan sebesar $0,000<0,005$, yang berarti

\section{SIMPULAN}

1. Rata-rata usia keluarga adalah 56 tahun, sebagaian besar berjenis kelami perempuan, pendidikan sebagian besar SD, pengalaman merawat penderita sebagain banyak penderita yang mengalami gangguan jiwa > 10tahun, sebagian besar responden bekerja dengan penghasilan rata-rata Rp500.000Rp1.000.00,-, serta sebagaian mempunyai hubungan dengan penderita sebagai ibu dari penderita.

2. Pengetahuan keluarga mengenai personal hygiene pada keluarga penderita yang mengalami gangguan jiwa dalam kategori baik dan cukup.

3. Kemampuan keluarga merawat pada keluarga penderita yang mengalami gangguan jiwa sebagian sebagain besar adalah mampu.

4. Hubungan pengetahuan keluarga tentang personal hygiene dengan kemampuan keluarga merawat, yang menunjukan hubungan berpola positif artinya semakin bertambah pengetahuan keluarga semakin bertambah pula kemampuan keluarga dalam merawat anggota keluarganya yang mengalami gangguan jiwa. 


\section{REFERENSI}

Damayanti, matia.2009. Efektivitas Tindakan Personal Hygiene Terhadap Tingkat Kepuasan Pasien. (online) www. fatmazdnrs logspot.com.diakses 15 maret 2015

Friedman. 2010. Buku Ajar Keperawatan Keluarga : Riset, Teori, \& Praktik. EGC: Jakarta

Hasriana. 2013. Faktor yang Berhubungan dengan Personal Hygiene pada Penerita Gangguan Jiwa di Rumah Sakit Khusus Daerah Provinsi Sulawesi Selatan. Volume 2 nomor 6.ISSN 2302-1721

Hawari, Dadang. 2001. Keperawatan Kesehatan Holistik pada Gangguan JIwa Sizofrenia. Gaya Baru: Jakarta

Notoatmodjo, S.2007. Pendidikan dan Perilaku Kesehatan. Rineka Cipta: Jakarta .2010. Metodologi Penelitian Kesehatan. Rineka Cipta: Jakarta.
2007. Promosi Kesehatan dan Ilmu Perilaku. Rineka Cipta :Jakarta

Riyandini.R.F.,Saraswati,H.R.,\& Meikawati.2011. Faktor-Faktor Yang Berhubungan Dengan Kekambuhan Pada Pasien Skizofrenia Di Rumah Sakit Jiwa Amino Gondotomo Semarang.

Riskesdas. 2013. Riset Kesehatan Dasar. Badan Penelitian Dan Pengembangan Kesehatan Kementerian Kesehatan RI

Teschinsky.F,.R(2007). Pengaruh Psikoedukasi Keluarga Terhadap Kemampuan Keluarga Volume 5. Purwokwerto: Jurnal Keperawatan Soedirman.

Videbeck, Sheila L.2008. Buku Ajar Keperawatan Jiwa. EGC: Jakarta

wawan.A \& Dewi.M. 2010. Teori Dan Pengukuran Pengetahuan, Sikap Dan Perilaku Manusia. Nuha Medika : Yogyakarta 